\title{
H.P.C. (3-HYDROXY-2-PHENYLCINCHONINIC ACID) IN RHEUMATOID ARTHRITIS*
}

\author{
BY \\ L. MANDEL and G. D. KERSLEY \\ From the Rheumatism Research Unit of the South West and Oxford Regions, \\ Royal National Hospital for Rheumatic Diseases, Bath
}

(RECEIVED FOR PUBLICATION DECEMBER 18, 1952)

Since the discovery of the anti-rheumatic effects of ACTH and cortisone by Hench, Kendall, Slocumb, and Polley (1949), many attempts have been made to find compounds which may have a similar action. In the investigation of the pharmacological properties of certain cinchoninic acid derivatives, Blanchard and others (1950a) found that the compound 3-hydroxy-2-phenylcinchoninic acid (H.P.C.) decreased the adrenal ascorbic acid content of the intact rat, but not of the hypophysectomized rat. They therefore suggested that H.P.C. might be effective in diseases which respond to ACTH, and reported a clinical trial in which the compound was given to ten patients with acute rheumatic fever, ten with chronic rheumatoid arthritis, three with bronchial asthma, and two with disseminated lupus erythematosus (Blanchard and others, 1950b). Fever, malaise, and arthritis were rapidly controlled in rheumatic fever, but in rheumatoid arthritis, although most patients improved subjectively, only two showed any objective change. The drug was administered orally, the dose being 10 to $20 \mathrm{mg}$./ $/ \mathrm{kg}$. body weight daily or on alternate days for periods up to 21 days.

The response to the compound in rheumatic fever was confirmed by Rennie and others (1951), who also found striking improvement in three patients suffering from scleroderma. The dose used was $20 \mathrm{mg}$. $/ \mathrm{kg}$. body weight daily, increasing to $40 \mathrm{mg}$. for 1 to 3 weeks.

Using a similar dose, Simson and Bunim (1951) reported marked improvement in six cases of rheumatic fever and also in four cases of gout. Of ten patients with rheumatoid arthritis, seven improved to a degree comparable to that obtained with salicylates, but not to that obtained with cortisone or ACTH. One or more toxic reactions occurred in six of the twenty patients treated, but in only four of these were the undesirable effects severe enough to necessitate interruption of therapy.

Toxic effects were also reported by Jager (1952) in

* Read to the Heberden Society on December 13, 1952. the treatment of 35 cases suffering from one of the $\frac{0}{2}$ so-called collagen disorders. The most common toxic $\vec{N}$ manifestations were skin eruptions (13 patients) and i diarrhoea (eight patients). The daily dose ranged $\vec{\omega}$ from 15 to $50 \mathrm{mg}$. $/ \mathrm{kg}$. body weight for periods varying from less than 1 month to 16 months. Of the 35 옥 patients treated, 21 were suffering from rheumatoid $\vec{c}$ arthritis. Although joint discomfort was relieved, $\subseteq$ the drug did not appear to alter the course of the $\vec{\sigma}$ disease, nor did it have any effect on the usual $\vec{\bullet}$ laboratory tests.

\section{Present Investigations}

In view of these promising reports, it was decided to conduct a controlled therapeutic trial of H.P.C. to $\frac{8}{8}$ evaluate its use in active rheumatoid arthritis. $\dagger$ In $\cong$ the first instance, a pilot series of 21 cases was $\overrightarrow{\overrightarrow{0}}$ investigated and in these control tablets were given 3 for a period and followed by the agent under trial. Subsequently, in another series of cases, 51 patients were given either H.P.C. or control tablets, the order of administration being selected at random. In both series, the identity of the inert substance and the agent under trial was, as far as possible, unknown to both patient and observer.

All the patients were suffering from active rheuma- 0 toid arthritis, and were initially treated in hospital with rest splints, remedial exercises, and physio- $\frac{D}{0}$ therapy for 2 weeks before the administration of the tablets was begun. Patients who were subsequently $N$ given maintenance therapy took the tablets after $N$ discharge from hospital and were seen at a special ్్ follow-up out-patient clinic.

Patients were assessed twice weekly whilst in hospital. Those receiving maintenance treatment $\stackrel{\circ}{C}$ were assessed as out-patients, after one month and $\stackrel{D}{\mathscr{D}}$ after 3 months of such treatment. The assessment

+ The drug was provided in the form of yellow tablets, each con-우 taining $200 \mathrm{mg}$. for oral administration, by Messrs. May and Baker, $\mathbb{D}$ who also supplied control tablets containing lactose, which were identical in appearance. 
was essentially clinical, attention being paid to general feeling of well-being, spontaneous pain (including rest pain), stiffness, joint tenderness, swelling, and range of movement, in addition to functional ability as indicated by the familiar and accustomed movements of everyday life. At all assessments, patients were weighed. Estimations of the erythrocyte sedimentation rate and haemoglobin level were done before and immediately after treatment in hospital, and at the time of all out-patient follow-up assessments.

Pilot Series.-The 21 patients in the pilot series were given control tablets for periods varying from 2 to 21 days (average 10 days), and were then all transferred (unknown to both patient and observer) to the H.P.C. tablets, which were continued for 10 to 36 days (average 20 days). The control tablets were always administered in exactly the same way as the H.P.C. tablets that followed. In all cases the initial dose of the drug was $1.2 \mathrm{~g}$. (six tablets) daily, this being equivalent to $20 \mathrm{mg}$./ $\mathrm{kg}$. of an average body weight of $60 \mathrm{~kg}$. (132 lb.). In order to reduce toxic effects to a minimum, the total daily dose was divided into three, taken in milk at hourly intervals, the first dose being taken after breakfast. The initial dose was continued until the patient either improved clinically or developed toxic symptoms. If neither change occurred after a week, the dose was increased to a maximum of $2.4 \mathrm{~g}$. daily. In some cases, the dose was reduced to $0.6 \mathrm{~g}$. daily because of toxic symptoms. In this way, an attempt was made to determine the optimum dose which would produce the maximal clinical benefit with minimal complications. This was found to be $1 \cdot 2 \mathrm{~g}$. daily.

The clinical results of the pilot series are shown in Table I, which demonstrates maximum clinical change. It can be seen that twenty patients improved on H.P.C. (fifteen markedly) compared with only twelve on control tablets (none markedly). Only one patient's condition was unchanged with the drug, whereas nine patients in the control group either showed no change or deteriorated. Analysis of the figures by the $\chi^{2}$ test shows that there is a marked statistically significant difference between treated and control, $p$ being less than $0 \cdot 01$.

TABLE I

MAXIMUM CLINICAL CHANGES IN PILOT SERIES OF 21 PATIENTS

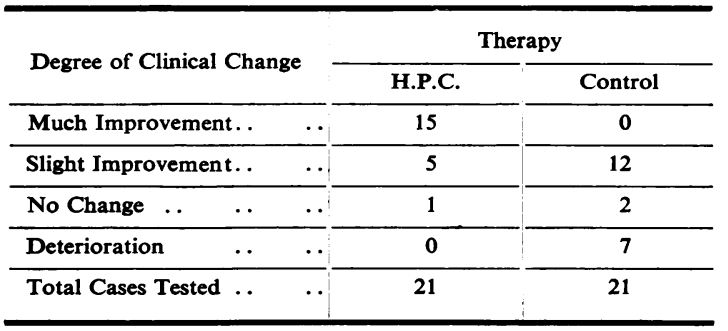

Random Selected Series.-Encouraged by this experience, a second series of cases, controlled by random sampling, was investigated. 51 patients were treated either with H.P.C. or with the control. H.P.C. was given to 26 patients and the control tablets to 25 . The dose of the former was standardized at $1 \cdot 2 \mathrm{~g}$. daily. This was continued for 21 days, the method of administration being the same as that employed in the pilot series. If, during this period, toxic symptoms developed with the H.P.C. either the drug was stopped or the dose was reduced to $0.6 \mathrm{~g}$. daily. At the end of the period, all patients in each group who showed marked improvement without toxic effects, took a maintenance dose of four tablets daily for 3 months. Such maintenance therapy was given to six patients taking control tablets and to eleven patients treated with H.P.C.

The clinical changes observed after 21 days treatment are shown in Table II. Although the proportion of "much improved" cases was greater with H.P.C. than with the control, statistical analysis of the figures shows that the difference between the treated and control groups may have occurred by chance, and is therefore not significant $(0 \cdot 30>$ $p>0 \cdot 20)$.

TABLE II

CLINICAL CHANGES AFTER 21 DAYS IN RANDOM SELECTED SERIES OF 51 PATIENTS

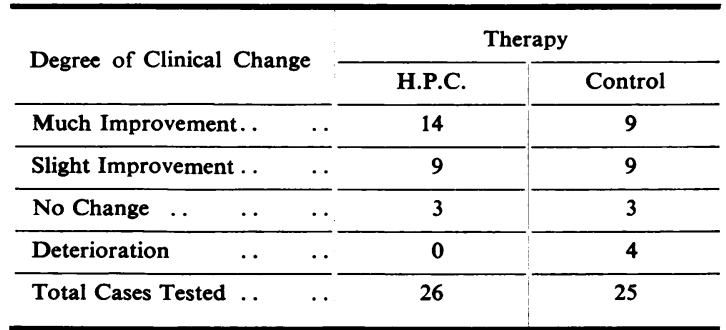

Of the eleven patients who continued with H.P.C. in maintenance doses, six retained their improvement after 3 months. None of the six control patients on maintenance therapy deteriorated after a similar period.

Sedimentation rates and haemoglobin levels were not significantly changed in either control or treated groups, nor was there any appreciable change in weight.

\section{Toxic Complications}

The most common toxic effects of H.P.C. were gastro-intestinal symptoms and skin eruptions. Neither of these disturbances occurred in patients taking control tablets.

Gastro-Intestinal Symptoms.-These included nausea, abdominal pain, and diarrhoea. They varied 
in severity from mild nausea with a feeling of abdominal discomfort to marked diarrhoea with colicky abdominal pains associated with general malaise and fever. In mild cases, the symptoms disappeared with the continued use of H.P.C. either spontaneously or with small doses of Mist. Kaolin B.P.C. The most severe symptoms usually occurred when the dose was increased to $2.4 \mathrm{~g}$. daily, and the drug had then to be discontinued in six out of nine patients who were taking this larger dose. Withdrawal of the drug because of troublesome diarrhoea was also necessary in seven out of 38 cases taking $1 \cdot 2 \mathrm{~g}$. daily. There were no gastro-intestinal disturbances with doses of $0.6 \mathrm{~g}$. and $0.8 \mathrm{~g}$. daily, although the latter was continued as maintenance therapy for 3 months. The onset of toxic effects did not necessarily coincide with maximal clinical improvement as is so frequently the case with aurotherapy.

Skin Eruptions.-Of the 21 cases in the pilot series, seven developed skin rashes. These were urticarial in nature, suggesting drug sensitivity, and they responded well to systemic and local antihistamine drugs. The eruptions developed on the exposed parts (particularly hands and face) and usually appeared on going into the open air, especially on exposure to sunlight. The drug was first used during the summer of 1951 when these skin reactions were first noticed. The random selected series was started in the autumn of 1951 and continued throughout the winter and into the summer of 1952. During the winter, skin reactions did not occur. When the summer weather began, however, the eruptions were again encountered, especially in those patients on maintenance therapy. Out of the eleven cases, nine developed skin rashes at some time during the 3 months' treatment. The eruptions again developed on the exposed parts, but often extended to the scalp, neck, and arms. They differed from those occurring in the previous summer in that they were chiefly vesicular, but erythematous and scaling forms were also seen. These skin rashes were often quite troublesome, the vesicular type becoming crusted, and the drug had to be stopped in three cases. As in the case of the gastro-intestinal toxic symptoms, there appeared to be no correlation between maximal clinical improvement and the onset of skin eruptions, nor was there any correlation between the two groups of toxic complications.

In view of the clinical evidence of photosensitivity in the pilot series, skin sensitivity tests were performed before, during, and immediately after the course of treatment in hospital in the random selected series. For this purpose an Alpine Sun
Hanovia lamp was used at a distance of 36 in. for half a minute and one minute, to a localized area of $\frac{\square}{\omega}$ normally unexposed skin (abdomen). There was complete lack of correlation between the develop- $\stackrel{\mathcal{O}}{\mathcal{O}}$ ment of skin eruptions and the response to ultra- $\bar{c}$ violet irradiation. During the winter months, several $\frac{\bar{\sigma}}{\bar{C}}$ patients became more sensitive to artificial sunlight $\frac{\bar{D}}{\vec{D}}$ during the course of treatment and yet developed no $\stackrel{\mathbb{Q}}{\Omega}$ rash. On the other hand, none of the patients who developed severe vesicular and erythematous erup-

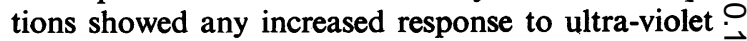
light from the artificial source.

\section{Summary and Conclusions}

In a pilot series of 21 cases, the patients were all $\vec{N}$ given control tablets for periods of 2 to 21 (average? 10) days and were then all transferred to H.P.C. $\vec{\omega}$ tablets for 10 to 36 (average 20) days. Twenty of $\mathrm{O}$ these patients showed improvement during the H.P.C. therapy, whereas only twelve had shown ${ }_{C}$ slight improvement while taking the control tablets.

In a second series of 51 cases, 26 patients were given $1 \cdot 2$ g. H.P.C. daily, and 25 received control $\vec{G}$ tablets. Fourteen treated cases and nine controls $\omega$ were much improved after 21 days, a proportion that could not have occurred by chance.

The excellent results in the pilot series are pro- $\frac{\partial}{0}$ bably misleading, as these patients were all given the control tablets before the drug, which was then con- $\stackrel{\square}{\varrho}$ tinued for a longer period. It is thus considered that $\overrightarrow{\vec{A}}$ the results of the second random selected series pro- $\frac{0}{3}$ vide a more reliable and accurate evaluation of the $\bar{P}$ efficacy of H.P.C. Although the proportion of patients in the second series who improved during H.P.C. therapy is greater than that of those whoo improved with the control tablets, the difference is not significant. The beneficial effect of H.P.C. in rheumatoid arthritis has thus not been conclusivelyô proven.

Furthermore, the toxic effects of the drug cannot? be minimized as they occurred in a high proportion $\square$ of cases and were often sufficiently severe to neces-ㅡㅡ. sitate withdrawal of therapy: 55 per cent. of patients taking $1.2 \mathrm{~g}$. daily developed some gastro-intestinal symptoms, and in one-third of these, the drug had to 0 be discontinued; skin eruptions of varying severity developed in nine out of eleven patients taking the drug for 3 months, and treatment had to be stoppedo in three. No relation between toxic effects andळ clinical improvement was noted.

We are indebted to Dr. R. Thrower, of Messrs. Mayo and Baker, for the supply of H.P.C. and control tablets. We would also like to thank Miss E. A. Worsp for carry ing out the skin sensitivity tests. 
REFERENCES

Blanchard, K. C., Dearborn, E. H., Maren, T. H., and Marshall, E. K. (1950a). Bull. Johns Hopk. Hosp., 86, 83.

- Harvey, A. M., Howard, J. E., K̉attus, A., Marshall, E. K. Newman, E. V., and Zubrod, C. G. (1950b). Ibid., 87, 50

Hench, P. S., Kendall, E. C., Slocumb, C. H., and Polley, H. F. (1949) Proc. Mayo Clin., 24, 181.

Jager, B. V. (1952). Bull. Johns Hopk. Hosp., 90, 121

Rennie, J. B., Milne, J. A., and Sommerville, J. (1951). Brit. med. J., $1,383$.

Simson, J., and Bunim, J. J. (1951). Amer. J. med. Sci., 222, 523.

H.P.C. (Acide 3-hydroxy-2 phényl cinchoninique) dans l'arthrite rhumatismale

RÉSUMÉ

Dans une série préliminaire de 21 cas, tous les malades reçurent pendant 2 à 21 (10 en moyenne) jours des comprimés inertes, suivis pendant 10 à 36 (20 en moyenne) jours de comprimés de H.P.C. Vingt de ces malades accusèrent une amélioration lors du traitement par l'H.P.C., tandis que douze seulement montrèrent une légère amélioration lors du traitement par les compriméstémoins.

Dans la deuxième série de 51 cas, 26 malades reçurent 1,2 g. d'H.P.C. par jour et 25 malades reçurent des comprimés inertes. Au bout de 21 jours, 14 cas traités et 9 témoins furent tres améliorés-une proportion qui pourrait être due au hasard.

Les excellents résultats dans la première série sont probablement fallacieux, car ces malades reçurent les comprimés inertes avant de recevoir le médicament, lequel fut ensuite administré pendant une période plus longue.

On considère donc que les résultats de la seconde série des cas pris au hasard permettent une évaluation plus sure et plus précise de l'efficacité de l'H.P.C. Bien que dans la seconde série le nombre des malades améliorés après l'H.P.C. soit supérieur à celui des malades témoins améliorés, la différence n'est pas signifiante. L'effet favorable de l'H.P.C. dans l'arthrite rhumatismale n'est donc pas irréfutablement prouvé.

De plus, il ne faut pas négliger les effets toxiques de ce médicament: ils survinrent dans un grand nombre des cas et furent souvent si graves qu'il fallut interrompre le traitement; $55 \%$ des malades prenant $1,2 \mathrm{mg}$. par jour manifestèrent des symptômes gastro-intestinaux et chez un tiers d'entre eux il fut nécessaire d'interrompre le traitement; des exanthèmes de sévérité variable apparurent chez 9 sur 11 malades prenant ce médicament pendant 3 mois et il fallut cesser le traitement chez 3 d'entre eux. On ne nota aucun rapport entre les effets toxiques et l'amélioration clinique.

\section{H.P.C. (Acido 3-hidroxi-2-feni cinconínico) en la artritis reumatoide}

\section{SUMARIO}

En la serie preliminar de 21 casos, todos los enfermos recibieron durante 2 a 21 ( 10 promedio) días comprimidos de control, seguidos durante 10 a 36 (20 promedio) días de comprimidos de H.P.C. Veinte de estos enfermos acusaron una mejoría durante el tratamiento por el H.P.C., mientras que doce de ellos solamente mostraron una ligera mejoría con los comprimidos de control.

En la segunda serie de 51 casos, 26 enfermos recibieron 1,2 g. de H.P.C. por día y 25 enfermos recibieron comprimidos de control. Al cabo de 21 días, 14 casos tratados y 9 controles acusaron mejoría-una proporción que podría deberse a la casualidad.

Los excelentes resultados en la primera series fueron probablemente delusorios, ya que estos enfermos recibieron los comprimidos de control antes de recibir el producto que fué luego administrado durante un período más prolongado.

Se considera, pués, que los resultados de la segunda serie de casos casualmente escogidos permiten una valoración más segura y más exacta de la eficacia del H.P.C. Aunque en la segunda serie el número de los enfermos mejorados con el H.P.C. sea superior al de los testigos majorados, la diferencia no es significante. El efecto beneficioso del H.P.C. en la artritis reumatoide no está, pués, conclusivamente probado.

Además, no se puede menospreciar los efectos tóxicos del producto: éstos ocurrieron en un gran número de los casos y fueron a menudo bastante graves para cesar el tratamiento; 55 por ciento de los enfermos tomando $1,2 \mathrm{mg}$. diarios manifestaron síntomas gastro-intestinales y en una tercera parte de ellos hubo que interrumpir la medicación; exantemas de severidad variable aparecieron en 9 sobre 11 enfermos tratados durante 3 meses necesitando la cesación de la cura en tres. No se halló relación alguna entre los efectos tóxicos y la mejoría clínica. 